\author{
Abstracta Iranica \\ Abstracta Iranica Revue bibliographique pour le domaine irano-aryen \\ Volume 32-33 | 2013 \\ Comptes rendus des publications de 2009-2010
}

\title{
Sadriddin Aynī. Ta'rikhi inqilobi fikrī dar Bukhoro
}

\section{Evelin Grassi}

\section{OpenEdition}

Journals

Édition électronique

URL : http://journals.openedition.org/abstractairanica/40142

DOI : 10.4000/abstractairanica.40142

ISSN : 1961-960X

Éditeur :

CNRS (UMR 7528 Mondes iraniens et indiens), Éditions de l'IFRI

Édition imprimée

Date de publication : 1 décembre 2013

ISSN : 0240-8910

\section{Référence électronique}

Evelin Grassi, «Sadriddin Aynī. Ta'rikhi inqilobi fikrī dar Bukhoro », Abstracta Iranica [En ligne], Volume 32-33 | 2013, document 213, mis en ligne le 01 juillet 2016, consulté le 26 septembre 2020. URL : http://journals.openedition.org/abstractairanica/40142; DOI : https://doi.org/10.4000/ abstractairanica.40142

Ce document a été généré automatiquement le 26 septembre 2020.

Tous droits réservés 


\title{
Sadriddin Aynī. Ta'rikhi inqilobi fikrī dar Bukhoro
}

\author{
Evelin Grassi
}

\section{RÉFÉRENCE}

Sadriddin Aynī. «Ta'rikhi inqilobi fikrī dar Bukhoro », in : K. Aynī, A. Qurbonov and B. Rahmatov, eds., Ensiklopediyai nasri tojiku fors [Encyclopaedia of Tajik-Farsi Prose], no. of volume not indicated, Dushanbe, Sarredaksiyai ilmii Ensiklopediyai millii tojik, 2010, p. 190-308. [History of the Bukhara Intellectual Revolution]

1 This work by Sadriddin Aynī (1878-1954), a man of letters, historian and scholar, deals with the history of the Bukhara Emirate during the period when the first Jadid reforms were spreading in Turkestan. Beginning with the opening of the first "new-method" school in 1908, Aynī describes Bukharan historical events until the dawn of the Russian Revolution in 1917. The "Introduction" by the editor, Kamol Aynī (1928-2010), Sadriddin's son, points out that the original manuscript, dated 1918 and written in Tajik Persian, was submitted to a Bukharan publishing house (p. 196). When Yūldosh Pūlod, an old friend of Aynī's who was a commissioner of the Bukhara People's Republic, informed him that, given the Republic's pan-Turkic cultural policy, Bukhara publishing houses would accept manuscripts in Uzbek only, Ayni translated it into that language. Probably because of the negative attitude of some leading Bukharan personalities toward Ayni's ideas, the work was not published however, not even in Uzbek (p. 196-197).

2 The Tajik-Persian original was lost, while the Uzbek version would later come out in an abridged version under the title of Bukhoro Inqilobi ta'rikhi uchun materiallar [Materials for a history of the Bukhara Revolution] in Moscow (Izdatel'stvo narodov, 1926). In the 1980s, the Tajik writer and scholar Rahim Hoshim retranslated the text from Uzbek into Tajik Persian as Ta'rikhi inqilobi Bukhoro [History of the Bukhara Revolution] and published it in Dushanbe (Adib, 1987). The manuscript of the original work in Tajik Persian was 
rediscovered in the late 1990s, approximately eighty years after it had been written. In 2005, it appeared as the 14th volume of the author's Kulliyot [Collected works] (ed. Kamol Aynī and Muhammadjon Umarov, Dushanbe, Matbuot). The work was also published in Iran under the title Tā'rïkh-e enqelāb-e fekrīye Bukhārā in an edition by Kamāl 'Aynī (Tehran, Surūsh, 1381sh./2002-3).

3 Respecting his father's wishes, Kamol Ayni defended the idea that the Ta'rikhi inqilobi fikri dar Bukhoro is to be the fifth book of Yoddoshtho [Reminiscences] (p. 199). The first four books, published between 1949 and 1954, covered the period 1882-1903: Ayni's childhood and youth in Bukhara (See my review in St. Ir. 40/1, 2011).

In addition to the work by Sadriddin Aynī, the volume of the Ensiklopediyai nasri tojiku fors under consideration herein includes two works by Ahmad Donish of Bukhara (1826/7-1897): Navodir-ul-vaqoe' (Porchaho) [Selections from "Rare Events"] (p. 35-114), and Risola yo mukhrasare az ta'rikhi saltanati khonadoni Manghitiya [Treatise being a summary of the history of the rule of the Manghit Dynasty] (p. 116-188).

\section{AUTEURS}

\section{EVELIN GRASSI}

Université de Naples 